ISSN 2411-4758 (Print) 2518-1602 (Online)

Native word in ethnocultural dimension, Drohobych, Posvit, 2021, pp. 53-62.

DOI: https://doi.org/10.24919/2411-4758.2021.211690

УДК $811.161 .2 ’ 37^{\prime} 42: 821.161 .2-31$

\title{
МОВНИЙ ОБРАЗ ЗЕМЛІ (НА МАТЕРІАЛІ РОМАНУ-ПАНОРАМИ М. МАТІОС «БУКОВА ЗЕМЛЯ»)
}

\author{
Анна ОГАР, \\ кандидат філологічних наук, старший викладач кафедри філологічних \\ дисииплін та методики їх викладання у початковій иколі, \\ Дрогобиџький державний педагогічний університет імені Івана \\ Франка (Украӥна, Дрогобич) annaogar@ukr.net
}

ORCID: http://orcid.org/0000-0002-4917-8008

Research ID: F-1096-2018 http://www.researcherid.com/rid/F-1096-2018

Статтю подано до редколегіï/The article is submitted to the editorial board:11.09.2020.

Статтю опубліковано/The article is published: 22.02.2021.

У статті проаналізовано мовний образ землі у творі М. Матіос «Букова Земля». 3'ясовано, щуо особливістю иъього образу є його широкоаспектність, всеохопність. Земля охоплює все, щуо на ній відбувається. Образ землі особливий щзе й тим, щзо авторка опускає багато елементів з традиційного семантичного наповнення лексеми-вербалізатора, натомість актуалізує нові смисли, такі, як богообраність, землечентричність, людинозорієнтованість. Найяскравіме землю характеризує діяльність на ній людини, на яку та теж впливає. Беззаперечно, ключовим в образі є й компонент краса, однак образ землі-ие симбіоз матеріального й духовного, конкретного й абстрактного, низького й високого.

Ключові слова: мовний образ; компонент образу; вербалізатор; мовна об'єктивація.

\section{VERBALIZATION OF THE CONCEPT LAND IN POETIC DISCOURSE SECOND HALF OF XX CENTURY}

Anna OHAR,

Ph.D. in Philology, senior lecturer, Department of philological sciences and techniques of teaching in elementary school, Drohobych Ivan Franko State Pedagogical University (Ukraine,Drohobych)annaogar@ukr.net 
Linguistic image can be defined as a verbal equivalent of the mental image of a particular object, abstraction or phenomenon in the minds of the people, which is formed on the basis of national conceptual and structural canons, also lexical and semantic features of the language system.

The image of the earth is special, unique for any ethnic group, any culture. The earth is one of the words-symbols that characterize the worldview of Ukrainians. Therefore, the purpose of the article is to analyze the linguistic expression of the image of the earth in the novel by M. Mathios "Beech Land».

The article analyzes the linguistic image of the earth in the work of M. Mathios "Beech Land». It was found that the peculiarity of this image is its wide aspect, comprehensiveness. The earth covers everything that happens on it. The image of the earth is also special in that the author omits much of the traditional semantic content of the verbalizer token, instead emphasizing new meanings, such as God's election, earth-centeredness, and human orientation. The earth is most vividly characterized by human activity on it, which is also influenced by the earth. Undoubtedly, the key component in the image is beauty, but the image of the earth is a symbiosis of the material and the spiritual, the concrete and the abstract, the low and the high.. For example, this image presupposes both the sacredness of the earth and its profaneness; the earth gives, but also takes away. The combination of such opposites in one image testifies to its high abstraction, ancient origin, long and complex formation, semantic capacity and self-sufficiency.

Key words: language image; image component; verbalizer; language objectification.

Постановка проблеми. Тенденції сучасного мовознавства визначають потребу дослідження мови як системи, що фіксує результати концептуалізації й категоризації представниками етносу довкілля і накидає на нього сплетену попередніми поколіннями сітку етнічної культури (Селіванова, 2012, с. 51). Разом із мовою людина засвоює закладену в іiі семантичних матрицях інформацію про світ, побут, спосіб життя, стосунки між людьми (Голубовская, 2002, с. 44). Сучасний мовець, отже, перебуває під упливом мовних стереотипів, вироблених упродовж усього розвитку національної мови. Сам процес пізнання детермінували позамовні чинники: культура, історія, міфологія, релігія, науковий поступ тощо, тобто усе, що історично зумовлювало світорозуміння.

Лінгвістика оперує певним арсеналом понять для вивчення мови в такому ключі, один із яких - мовний образ. Мовний образ можна означити як вербальний відповідник ментального образу певного предмета, абстракції чи явища у свідомості народу, що формується на основі національних концептуально-структурних канонів та лексико-семантичних особливостей відповідної мовної системи (Щепанська, 2012, с. 157). Тобто мовний образ - це реалія чи абстракція, схоплена думкою 
й виражена мовою певного народу; це те із ментального згустка інформації про предмет, явище чи подію, що отримало мовну об'єктивацію. До слова, концепт передбачає весь обшир даних про певний об'єкт - i мовно прихованих, і явних. За особливостями мовного вираження певного явища можна простежити особливості його трактування в культурі, тобто мовний образ варто розуміти широко - як такий, що вербалізує взаємодію і взаємозв'язок культури та мови й відбиває цей процес як цілісну структуру в єдності мовного та позамовного (культурного) змісту 3 орієнтацією на пріоритети й культурні настанови (Сукаленко, 2014, с. 23). Мовний образ обов'язково передбачає культурне навантаження й передає його. Як цілісне поняття мовний образ охоплює певну сукупність смислів, тісно переплетених у неповторній комбінації, що до певної міри унеможливлює їх розклад на окремі елементи. Усе ж з метою наукового аналізу доцільно виокремлювати в образі певні значеннєві компоненти, інтерпретувати їх та класифікувати на основі певних ознак. Окрім найочевиднішої - семантичної, важливими також $є$ частота й способи вербалізації, адже з усього ментального континууму ословлення отримує те, що з тих чи тих причин актуальне для людини, іiі життя. А те, як часто говорять про нього, лише підтверджує цю актуальність. Різноманіття способів матеріалізації свідчить про грунтовне осмислення реалії, а вся парадигма вербальних виявів образу дає змогу простежити особливості їі трактування.

Аналіз досліджень. Образ земля - особливий, непересічний для будь-якого етносу, будь-якої культури. Н. Бабич (Бабич, 2013) зараховує землю до слів-символів, що характеризують світовідчуття українців (навіть ширше - землеробських народів, зокрема християнського релігійного світогляду). Тож зрозуміло, що досліджень, об’єктом вивчення яких $\epsilon$ ця ментальна одиниця, вдосталь. Серед останніх назвемо працю Т. Брікнер (Брінкер, 2020) про семантику мовного образу землі у фразеологізмах Франкової прози. Дослідниця доводить, що цей образ отримує широку фразеологічну інтерпретацію. Такий висновок є додатковим свідченням непересічності образу землі, адже здатність до фразеотворення притаманна лише релевантним одиницям.

I. Сирко (Сирко, 2013) зазначає, що сучасний досвід осмислення образу земля як «етномаркованого мовно-естетичного знака поки що не забезпечує повного опису його лексико-семантичної, тропеїчної та аксіологічно-оцінної парадигм, оскільки не охоплює усіх типів дискурсів, усіх жанрових різновидів текстів, у яких образ земля виявляє свою стилістичну, мовновиражальну актуальність». Дослідження ж мовної об’єктивації образу виявляє його структурну складність, за- 
свідчену різноманітними контекстами, модифікаціями смислових та оцінних значень. Мовно-когнітивне розростання образу земля передбачає надбудову як узвичаєних семантичних компонентів, так і неологічних, авторських.

Мета статті - проаналізувати мовне оформлення образу землі в романі М. Матіос «Букова Земля».

Виклад основного матеріалу. Дослідження одиниць мовно-ментального плану відбувається за певною, чітко аргументованою схемою, обгрунтованою методикою, що здебільшого передбачає певне структурування. Особливістю мовного образу земля в романі-панорамі М. Матіос «Букова Земля» $\epsilon$ його широкоаспектність, всеохопність. Земля охоплює все, що на ній відбувається. Людина, іiі життя і смерть, ііі доля та всі перипетії, пов'язані з нею, насправді й надають значущості, вагомості землі, бо саме людина робить певну ментальну одиницю вагомою, маркуючи їі, надаючи їй певної оцінки. Однак не безпідставно. Лиш вагомі об'єкти, ті, які суттєво (позитивно чи негативно) впливають на її життя, людина виділяє. I що вагоміший цей вплив, то чільніше місце відведено відповідній одиниці в картині світу етносу.

Образ землі в тексті особливий й тим, що авторка опускає багато елементів 3 традиційного семантичного наповнення лексеми-вербалізатора, натомість наділяє їі новими значеннями. Скажімо, лексикографічно зафіксовані семи не найцікавіші в творі як той мінімум, який читачеві відомий як члену певної культурної спільноти. Мисткиня оперує тим, що вважає характерним, автентичним для певної землі, яка репрезентує образ землі загалом. Так, земля як грунт, який обробляють для вирощування рослин, поле - це усталений і непримітний образ, хоч присутній у романі. Він ілюструє таку естетизовану рису психотипу українців, як працьовитість, і «рису» землі поглинати працю, вимагати в тих, хто іiі освоює, важкої, виснажливої роботи, а натомість щедро віддячувати плодами. Однак значно яскравішим, концептуальнішим для роману $є$ образ землі як поля діяльності Бога, образ злиття землі та людини: Оcь наше щуоденно переорюване поле. ... Ось мій улюблений полігон для випробувань. Земля і люди. Люди $і$ земля (с. 33).

За біблійними переказами, земне життя - це місце болю і страждань, «суєта суєт» на противагу небу-раю: На иій крихітній долоньц̧і Землі $і$ тепер триває життєва метушня в усій ї̈ багатоманітності (с. 33). Однак навіть уся життєва рутина, всі випробування й негаразди не затьмарюють краси Землі, іiї принадності. Трактування Землі як пекельного місця урівноважується ііі трактуванням як раю. Безперечно, провідним в образі землі обстежуваного тексту є компонент краса. Роз- 
логі, детальні описи, замальовки краю просто вихлюпують захоплення авторки земною красою, іï любов до позначеного Богом клаптика землі. Творець облюбував собі Букову Землю. Саме богообраність є визначальною характеристикою землі в однойменному романі:

Хтозна... може, на зорі започаткування світу Бог і справді мав намір виокремити на всій землі особливий куточок - i тому створив густонаселений живою природою справжній рай, в надії, що навіть його безсмертна душа таки коли-не-коли, а все ж відпрошуватиметься усамітнюватися... (c. 37).

Наступною віхою обстежуваного образу є землецентричність. Земля $\epsilon$ тим осердям, довкола якого обертається життя людини: вона годує, напуває, одягає, звеселяє i, зрештою, забирає. Земля настільки важлива в житті буковинця, що слугує мірилом не тільки майнового статусу, а й еталоном оцінювання власних дітей:

У Берегівчука тільки тої жменьки землі, що зміг придбати своїм горбом і руками: по фальчі грунту на кожного сина і по п'ять пражин на доньку Килину і на Гафію. ... Тимофій росте хитрий - він ніколи в житті не пропаде навіть без землі. А Гафія хоч до землі охоча, та Дарій не знає, чи буде 3 неї добра газдиня (с. 197)

Однак Букова Земля не асоціюється з пригніченням, 3 рабством, 3 безпросвітністю, як про це пише Франко, аналізуючи її образ у літературі. «Земля ненаситна у своїй жадобі, вона поглинає працю і піт численних поколінь, висисає 3 них силу, думку, ціле життя, а по смерті навіть їхні тіла. Вона домагається все нових жертв...» (Франко, 1980 , с. 185). Букова Земля вимагає тяжкої праці, однак вона добра, вона - мати. У романі людина зливається воєдино з землею, а земля 3 людиною. Давні вірування про походження людини із землі, про землю-матір, що годує, дає сили, надихає; побут, зусібіч пов'язаний iз землею, спричинився до ототожнення людини з землею: без неї та б не вижила, але й земля потребує праці й догляду, потребує когось годувати, напувати, підтримувати: «Чи можемо ми байдуже спостерігати, як потребують людської підтримки землі-тепер уже наші землі, - жорстоко проріджені війнами, епідеміями $і$ політичними змовами? Адже якщуо на незаселеній, але благодатній, землі не буде людей - то не буде кому ї̈ захищати...» (с. 50). Земля - таке божество, яке не змогло посунути навіть християнське віровчення. Бажання й молитви людини збігаються з благаннями землі, зливаються 
«в одночасному екстазі землі і людини, коли звучать усесвітні хори прохань, благань і самодіяльних молитов людьми різних рас і різних мов, різної віри і звичаю» (с. 15).

...бо так воно $\epsilon$ в безконечному світі, що денно і нощно, у спеку і в зливу, у суховії і в заметілі, під час баталій і перемир'я, у мить народження і в годину смерті витають над Землею безконечні людські молитви... < .. > Ізвідкись із гарячих глибин скам'янілої земної тверді чи із не менш пекельних надр і непізнаного мороку людської природи виринають ті дивні, неперервні співи - не співи, заклинання - не заклинання, а лише тремкі оболонки людського єства і духу, укладені в молитву. І пливуть вони без поспіху і без зупину ... нечутно всотуючись у земні і небесні звуки, переливаючись, немов у жбанки, із людського горла у горло матері-землі - і далі вертають із землі до людини, створюючи безконечний колообіг благання (с. 15).

Спрямовані з землі заклики, за версією авторки, вертаються до людини, «найпростіші слова стають охоронними, оборонними щитами-молитвами, а молитви - спасенними хорами, щоб розтікатися від землі до неба і від небес до землі невловимими струменями чудодійної сили» (с. 15). Земля втілює одночасно й профанне, і священне: вона i вболіває разом з людиною, і вислуховує їі благання. Земля наділена людськими якостями і якостями сакральними, а поєднання в одному образі таких протилежних рис засвідчує його високу абстрагованість, давнє зародження, тривале й складне становлення, смислову місткість та самодостатність. Це додає обстежуваному тексту семантичного синкретизму. С. Срмоленко зазначає, що «в конкретному слововживанні сполучуваність цієї лексеми [земля] виявляє об'єднання, перехід одного значення в інше» (Срмоленко, 2007, с. 308). Навіть більше: номен земля здебільшого об'єднує кілька значень, однак характер цих об’єднань різний. Від тісного зрощення смислів, що унеможливлює їхнє розщеплення без втрати цілісності образу, до сполучень, у яких земля постає в різних іпостасях, однак один із смислів пріоритетний, акцентований, хоч таке його виділення не нівелює інших компонентів. Додамо, в продовження теми:

...І цими чи іншими наболілими словами вже говорить начебто й не жива людина - а сама до себе звертається напрацьована земля, що зазвичай дихає рівно, як дихає здорова людина, не думаючи про тривогу чи лихо (c. 16).

Авторка підкреслює «людську» іпостась землі метафорними формами напрацьована, як дихає здорова людина, говорить словами, не ду- 
маючи про тривогу, дихає рівно. І тут же: сама до себе звертається земля, тобто земля є і адресатом людських молитов, і вищою силою, на яку люди покладають надії. Бо поряд читаємо: $\ddot{I}$ [молитви] ніколи не вертає назад ні земля, ні небо, бо вони, небо $і$ земля невтомні, слухати безконечні людські заклинання (с. 16). Земля урівняна з небом - місцем перебування Бога, ангелів, святих, із раєм.

Земля не лише констатує належність людини до певної території, а й впливає на ментальність і життя, є їі духовним атрибутом. Людина не лише ступає по своїй землі, а носить їі усередині себе як певну духовну категорію. Букова Земля немов формує характер своїх мешканців - у міру добрий, у міру впертий, працьовитий, наполегливий... Земля підтримує, надає сили, снаги. Як і земля, людина - створіння складне, суперечливе. Образ людини об'єднує антагоністичні компоненти, здавалось би, непоєднувані в одне ціле. Однак читаємо:

Дозволив їм війни, падіння моралі, безконечні і нестримні оргії. Інцести. Збоченства. Взаємопоборювання. Так. Мені було нестерпно важко спостерігати, до якого дна може дійти падіння людини. I це після злетів духу, воїнської відваги, розквіту філософської думки, високого мистецтва! (с. 35)

Людина як земна істота з великого розуму чи, навпаки, через велику немудрість (знову поєднання протилежностей) втручається у Вищий промисел, стає (чи намагається стати) в один ряд із Вищим розумом, iз Богом. I це штучне піднесення переходить такі межі, що провокує на небесах запитання: «А Ви [Отче] не боїтеся конкуренції із земним розумом?» (с. 34).

Людина не лише невіддільна від своєї землі, а й невіддільна від їі історії - від своїх предків та нащадків. Людина немов ланка земного ланцюга: на зміну одним приходять інші, забезпечуючи так свою невмирущість, тяглість свого роду. Однак не лише перебрати естафету в цьому безперервному ланцюгу життя, а й пронести по ньому історію: взяти в одних, доповнити своїми здобутками й передати іншим, адже «Кожна людина велика. I навіть по смерті. Тому час до часу варто нагадувати про неї» (с. 43). Пам'ять про минуле так само важлива для людини, як і надія на майбутнє. Вона до певної міри робить людину відмінною від земного, наближеною до божественного: «Ця робота - нагадування про минуле - неперервна. Коли ми нею нехтуємо - живі розв'язують війни. Від незнання, захланності та інтелектуальних лінощуів» (с. 43).

В образі людини в такий спосіб поєднано мізерність, нікчемність i велич, маєстатичність. Маленька людина, така беззахисна, яка приходить у світ не з власної волі й так само іде, на яку чатують безліч 
небезпек, життя якої нічого не важить, власним зусиллям може стати такою величною, сягати такої висоти духу, вивищити себе над земним рівнем і сягнути божественного. Людська велич і героїзм утворює в образі той сегмент, який не протиставляється божественному, а урівнюється $з$ ним, пор.:

[Бог:] Але інколи людина таки перемагає мене силою своєї волі - умінням не боятися. Зокрема й Смерті. ... I я, вічний і безсмертний, дотепер не можу пояснити, чому так багато людей іде на смерть, на самопожертву в ім’я, на перший погляд, якихось цілком ефемерних, нефункціональних речей і понять....... Або - чому людина бере до рук зброю і йде захищати землю, їй не належну іншим чином, як просто знаючи, що ця земля є іiї батьківщиною, iï країною чи землею іiі батьків? ... А у мене вони, бачите, - обрані (с. 31)

Така ірраціональність людської поведінки спричинює витворення касти героїв, що демонструє сакральне в людині, взяте від іiі Сотворителя, а це робить їі сильнішою від Творця (с. 30). Тобто в створеній Богом земній істоті є не лише низьке, а й високе, небесне. Усе високе людина демонструє перед лицем Смерті, яка в парі із Життям супроводжує людину, бо «життя - це винятково рух до смерті через особисте вдосконалення» (с. 29). Життя ж - це дар, але не тільки: «А люди не менш ретельно виконували єдину примусову роботу від Бога, не знаючи, що вона називається просто і коротко - ЖИТТЯ» (с. 33). А смерть «це виховання живих» (с. 43), це «абортоване земне зло» (с. 26). Життя і смерть, добро і зло - одвічні супутники людини; битва між ними творить іiі земне буття. Витлумачення цих надважливих філософських понять через художню мову демонструє релігійність Букової Землі, за якою «над Творцем немає нікого ні там, коло самого Сонця, ні у надрах землі» (с. 27). Упованням на Бога просякнуте все життя людини, однак воно не заперечує могуті впливу самої людини, яка має простір для удосконалення (с. 28). Поряд з орієнтирами-гігантами ще безліч дрібних людських пристрастей творять історію такої принадної землі, доля якої випробовувала її війнами, розрухами, хворобами та голодом. Безліч людських історій зливаються в одну - в історію Букової Землі, землі, яку так щедро благословив Бог.

Висновки та перспективи подальшого дослідження. Здебільшого компоненти мовного образу земля характеризуються опозитивною структурою, об'єднуючи суперечливі складники. Складність архітектоніки образу (і формальна, і змістова) є свідченням складного процесу становлення образу, що передбачає і часте апелювання до нього, і різнобічне осмислення, деталізацію та розгалуженість, вели- 
кий радіус асоціативного кола. Уживання в образі древніх міфічних сенсів 3 християнськими віруваннями та науковими даними лише відтіняє давність зародження образу і додає, отже, ще значні темпоральні характеристики до цієї складної структури. Усе це, ясна річ, можливе лиш для вкрай актуальних утворень мовно-ментального простору.

Визначальною рисою образу земля є його широкоаспектність, всеохопність. Також авторка викристалізовує нові смисли, скажімо, богообраність, землецентричність, людинозорієнтованість. Яскраво зображує землю діяльність ії мешканців. Образ землі - це симбіоз матеріального й духовного, конкретного й абстрактного, низького й високого. «Букова Земля» - це не лише про землю. Це насамперед про історію людей на землі, про людську гідність, про людські злети й падіння, про любов і ненависть.

\section{ВИКОРИСТАНЕ ДЖЕРЕЛО}

Матіос, Марія. (2019). БУКОВА ЗЕМЛЯ. Роман-панорама завдовжки у 225 років. Київ: А-БА-БА-Га-ЛА-МА-ГА.

Matios, Mariia. (2019). BUKOVA ZEMLYA [BEECH LAND]. Roman-panorama zavdovzhky u 225 rokiv [A 225-year-long panoramic novel]. Kyiv: A-BA-BA-HALA-MA-HA.

\section{СПИСОК ЛІТЕРАТУРИ}

Бабич, Н. (2013). Мовні стереотипи з компонентами небо/земля в ментальному світосприйнятті українців. Волинь філологічна: текст і контекст, 15 , $31-41$.

Брінкер, Тетяна. (2020). Семантика мовного образу землі у фразеологізмах Франкової прози. Вісник Львівського університету. Серія філологічна, 72, 251 - 259. DOI: http://dx.doi.org/10.30970/vpl.2020.72.10927

Голубовская, И. А. (2002). Этнические особенности языкових картин мира. Киев : Издательско-полиграфический центр «Киевский университет».

Єрмоленко, С. (2007). Мова і украӥнознавчий світогляд. Київ: НДІУ.

Селіванова, О. О. (2012). Світ свідомості в мові. Мир сознания в языке. Черкаси : Ю. Чабаненко.

Сирко, Ірина. (2013). Семантико-аксіологічна парадигма образу земля в діаспорному щоденниковому тексті (на матеріалі щоденника М. Галабурди-Чигрин). Лінгвістичні дослідження: Зб. наук. пращь ХНПУ ім. Г.С. Сковороди, 35, $173-178$.

Сукаленко, Т. М. (2010). Метафоричне вираження концепту жінка в українській мові. Київ: Інститут української мови ; Видавничий дім Дмитра Бураго.

Франко, І. Я. (1980). Влада землі у сучасному романі. Зібрання творів у 50-и томах (Т. 28). Київ: Наукова думка. 


\section{REFERENCES}

Babych, N. (2013). Movni stereotypy z komponentamy nebo/zemlya V mentalnomu svitospryynyatti ukrayintsiv [Linguistic stereotypes with the components of heaven / earth in the mental worldview of Ukrainians]. Volyn filolohichna: tekst $i$ kontekst - Volyn philological: text and context, 15, 31 - 41. [in Ukrainian]

Brinker, Tatiana. (2020). Semantyka movnoho obrazu zemli u frazeolohizmakh Frankovoyi prozy [Semantics of the linguistic image of the earth in the phraseology of Franko's prose]. Visnyk Lvivskoho universytetu. Seriya filolohichna - Bulletin of Lviv University. The series is philological, 72, 251-259. DOI: http://dx.doi.org/10.30970/ vpl.2020.72.10927 [in Ukrainian]

Golubovskaya, I. A. (2002). Étnycheskye osobennosty yazykovykh kartyn myra: monohrafyia [Ethnic features of linguistic pictures of the world: monograph]. Kyiv: Kyiv University Publishing and Printing Center. [in Russian]

Yermolenko, S. (2007). Mova i ukrayinoznavchyy svitohlyad [Language and Ukrainian studies worldview]. Kyiv: NDIU. [in Ukrainian]

Selivanova, O. O. (2012). Svit svidomosti v movi. Myr soznanyya v yazyke [The world of consciousness in language]. Cherkasy: Yu. Chabanenko. [in Ukrainian]

Sirko, Irina. (2013). Semantyko-aksiolohichna paradyhma obrazu zemlya v diaspornomu shchodennykovomu teksti (na materiali shchodennyka M. HalaburdyChyhryn). [Semantic-axiological paradigm of the image of the earth in the diasporic diary text (on the material of the diary of M. Galaburda-Chigrin)]. Linhvistychni doslidzhennya: Zb. nauk. prats KHNPU im. H.S. Skovorody - Linguistic research: Coll. Science. Gregory Skovoroda KhNPU. Frying pans, 35, 173 - 178. [in Ukrainian]

Sukalenko, T. M. (2010). Metaforychne vyrazhennya kontseptu zhinka $v$ ukrayinskiy movi [Metaphorical expression of the concept woman in the Ukrainian language]. Kyiv: Institute of the Ukrainian Language; Dmytro Burago Publishing House. [in Ukrainian]

Franco, I. Ya. (1980). Vlada zemli u suchasnomu romani. [The power of land in the modern novel]. Zibrannya tvoriv u 50-y tomakh - Collection of works in 50 volumes (Vol. 28). Kyiv: Scientific thought. [in Ukrainian] 